\title{
The Relationship between Voluntary Disclosure and Company Performances on Interim Reports in Jordan Using the Method of Causality Directions
}

\author{
Ala' Hussein Albawwat ${ }^{1}$, Mohamad Yazis Ali Basah ${ }^{1} \&$ Khairil Faizal Khairi ${ }^{1}$ \\ ${ }^{1}$ Faculty of Economics and Muamalat, Universiti Sains Islam Malaysia (USIM), Malaysia \\ Correspondence: Ala' Hussein Albawwat, Faculty of Economics and Muamalat, Universiti Sains Islam Malaysia \\ (USIM), Bandar Baru Nilai, 71800 Nilai, Negeri Sembilan, Malaysia. E-mail: bawwat_alaa@yahoo.com
}

Received: April 11, 2015

doi:10.5539/ijef.v7n7p217
Accepted: April 28, 2015

Online Published: June 25, 2015

URL: http://dx.doi.org/10.5539/ijef.v7n7p217

\begin{abstract}
The focal point of this study is on voluntary disclosure in interim financial reports of the ASE listed companies in Jordan. The initiatives of voluntary disclosure have been under global scrutiny since the last two decades, owing to various stakeholders' persistent needs to be more informed about their corporations. As the mandatory corporate disclosure itself is insufficient, the study attempts to assess the directions of causality between the degree of voluntary disclosure and corporate performance in the half-yearly reports released by companies listed in the Jordan's ASE for the period of 5 years (2009-2013). The Granger tests were employed to ascertain the causality between voluntary disclosures and corporate performance in the half-yearly reports. From the test outcomes, most companies (50) show no directional causality, 21 companies demonstrate unidirectional causality while one company has bidirectional causality. The quality of voluntary disclosure appears to have high correlation with the performance of companies their half-yearly reports. Thus, high levels of transparency and quality of disclosure lead to good governance and enhance company's performance, while low voluntary disclosure makes it more difficult to forecast the company's performance.
\end{abstract}

Keywords: interim reports, voluntary disclosure, interim reports, corporate performance

\section{Introduction}

Stakeholders attach importance to voluntary disclosure because it feeds them with the much needed information to decrease uncertainty and aids them when making the right economic and financial decisions (Cooke, 1989). Additionally, attaining economic stability and the promotion of sustainable high quality investment by corporations are made easier by voluntary disclosure's transparency. This is made possible via financial reports released by companies. In fact, Lang and Lundholm (1993), and Betosan (1997) documented financial reports as a vital source of information to outsiders.

According to Barko, Hancock, and Izan (2006), companies can use financial reports to convey corporate information, quantitative and qualitative, to their stakeholders or to other parties with interest. Additionally, the quality of voluntary disclosure appears to have high correlation with the performance of firm (Mitton, 2002). Thus, sound governance can be attained and the performance of firm can be enhanced when transparency and quality of disclosure are high. On the other hand, Chang, Cho, and Shin (2007) contended that it would be more difficult for the market to predict the performance of firm when the level of voluntary disclosure is low.

Creditors and investors find information in interim financial reports useful for their decision making process, and thus, the level of information disclosure is a crucial feature in interim financial reports (Albawwat et al., 2014). Aside from that, the interim financial reports become the consistent source to creditors and investors for obtaining the most updated information on the companies' wellbeing. In relation to this, Saravanakumar et al. (2012) reported that many stock exchanges all over the world today require companies to release interim financial reports so that the primary stakeholders such as the investors, shareholders and employees would be provided with high quality financial information in a timely manner. This would also provide assistance in these stakeholders' investment and financing decisions.

Aside from that, Mangena and Tauringana (2007) reported a significant amount of citations in the literature pertaining to the value of interim reports in the decision making process of stock market investors. In relation to 
this, Allen et al. (1999) and Alias et al. (2009) documented that these reports supply investors with pertinent, dependable and newest material information with regard to the financial standing of the publicly listed companies, enabling them to make informed investment decisions, particularly, in earnings and share prices' predictions.

Reevaluation and corruptions have negatively impacted Jordan's economic growth. On top of that, the country's economy is being burdened by the government's colossal debts, and also by some issues related to economy including the financial crisis which had plagued the country in 2008. Jordan's public debt was at JD 19 billion in 2013 (IMF, 2014), and this had impaired the country's effort of luring foreign investors to come in, especially those from the developed nations. Apart from that, Jordan has also suffered the impacts of several other economic and political incidences which had occurred within the 2005 to 2013 period. These include the Arab Spring and the formation of the Islamic State of Iraq and al-Sham (ISIS). In fact, during this particular period, the country's corporate performance went down, causing economic destabilization (CBJ, 2014).

Returning to the matter of interim financial reports, the listed companies are required to publish them. In fact, Albawwat et al. (2014) documented that investors in Jordan used the interim financial reports and these reports are regarded as useful, and has been ranked the second most crucial source of information. As such, to fulfil the primary objective of this study, the directions of causality (bidirectional, unidirectional or neutral) between voluntary disclosure and company performance in the half-yearly financial reports released by the listed companies in Jordan will be investigated.

\section{Hypothesis Development}

A number researchers such as Wallace and Naser (1996), Ahmed and Courtis (1999), Haniffa and Cook (2002), Camfferman and Cooke (2002), Chau and Gray (2002), Akhtaruddin, (2005), Barako et al. (2006) and Adelopo (2011) have tested the relationship between corporate performance and the degree of voluntary disclosure in the annual reports, and came up with mixed results. For instance, Wallace and Naser (1996), Haniffa and Cook (2002), Camfferman and Cooke (2002), Chau and Gray (2002) and Adelopo (2011) documented a positively significant relationship between corporate performance and the degree of voluntary disclosure, while Ahmed and Courtis (1999), Akhtaruddin (2005) and Barako et al. (2006) found no statistical significance in the relationship.

Somehow, albeit the mixed outcomes, it is possible to find directions causality between the extent of voluntary disclosure and corporate performance. This directions causality can be explained by the signaling theory, where corporate performance may have the incentive to signal that they are batter companies by providing more voluntary disclosure within their interim reports. The company having higher corporate performance would be due to several aspects including voluntary disclosure, resulting in high voluntary disclosure.

Aside from that, the annual reports' voluntary disclosures transmit signals to the marketplace (Gordon et al., 2010). It is expected that these signals would increase the net present value of the company, which will also increase the company's stock market value. On the other hand, the act of non-disclosure is assumed by investors as company hiding 'bad news' (Lev \& Penman, 1990). As such, voluntary disclosure becomes the motivation of the good-news firms to distinguish themselves from the bad news counterparts. Thus, it can be said that when corporate performance of a company is increased, the company's voluntary disclosure will also increase.

In an attempt to raise capital, companies with high level of corporate performance are motivated to distinguish themselves from those companies with lower level of corporate performance by releasing voluntary disclosure (Foster, 1986). Aside from that, the management of the high corporate performance companies is motivated to release more information because information disclosure could increase investors' confidence, and this will increase the management's compensation and further, support their position. Thus, based on the aforementioned, the formulated hypothesis is as below:

H1: There are different directions of causality (bidirectional, unidirectional, and neutral) between voluntary disclosure and corporate performance in the half-yearly reports published by the ASE listed companies in Jordan.

\section{Methodology}

\subsection{Data}

The focus of the study is on the interim reports (half-yearly) mandated by the Directives for Listing Securities published by the Amman Stock Exchange that were published by the listed companies during the 2009-2013 period. In particular, 72 listed companies have been selected. Further, since the financial sector is governed by financial reporting's special regulations by the Central Bank of Jordan and the Insurance Commission, only non-financial companies were selected for this study. 
As for the companies and the time frame chosen, their selection was according to data availability and completeness. With respect to the data gathered, they are all from the first-half of the interim financial reports. Meanwhile, data from the second half of the interim report are not selected as they can also be found in the annual report. As for the data from the first part of interim report, they are crucial for the users (Mathuva, 2012).

\subsection{The Disclosure Index}

Formulating the voluntary disclosure index is the primary task for this research type. This index functions as the measurement tool in gauging the degree of voluntary disclosure, mandatory disclosure or both of them. As explained by Arvidsson (2003), the disclosure index comprises of a disclosure checklist that includes certain items of disclosure. As for the current study, the focus is on the degree of voluntary disclosure published in the half-yearly reports of the listed companies in Jordan.

However, as indicated by Wallace, Naser and Mora (1994) and Bukh, Nielsen, Gormsen and Mouritsen (2005), the available literature on disclosure has provided no concrete theoretical framework, or guidelines on the appropriate amount or the specification of items to be included in the index. Owing to this matter, the study has taken the following steps during the formulation of voluntary disclosure index:

1) During index construction, a voluntary disclosure checklist is formed to reflect the information mandated by the listing requirements of Amman Stock Exchange, the Company Law No. 76 of 2002 and the IFRSs.

2) The selections of the past studies are used as guideline. Among these studies are those by Cooke (1989), Meek et al. (1995), Eng and Mak (2003), Ghazali and Weetman (2006), Akhtaruddin and Haron (2010), Al-Shammari and Al-Sultan (2010), Elsayed and Hoque (2010), Lopes and Alencar (2010) and Adelopo (2011). Further, the index's applicability in the context of Jordan is also scrutinized. The underlying rationale for this is that, current knowledge is often based on the past findings. Then, a total of 65 preliminary voluntary disclosure items were developed for this study.

3) The preliminary disclosure index developed in this study was checked against the compulsory half-yearly report disclosure in the Amman Stock Exchange in order to ascertain that the index reflects items of voluntary disclosure only. Then, the index was sent to two expert accountants from the ASE to have it refined and validated. After the necessary adjustment was made, the now finalized and validated index contains 56 items.

4) The items of the finalized index are then divided based on the three major groups of voluntary disclosure: items of strategic information, items of non-financial information and items of financial information.

For the disclosure index scoring, the unweighted approach appears to be more appropriate and thus, it is chosen for this study. There are three rationales for utilizing the unweighted approach: 1) to avoid the high subjectivity associated with the weights of items of importance's assignment by dissimilar user groups, and this view is supported by Raffournier (1995) and Bukh et al. (2005), 2) assuming that all disclosure items are equal will yield lower bias, compared to the weighted approach which results in inaccurate weighting (Raffournier, 1995), and 3) there are scholars (i.e., Robbins \& Austin, 1986); Chow and Wong-Boren (1987) who found no difference in results between the weighted and unweighted approach.

In Mathematical expression, voluntary disclosure index is a ratio or percentage of the actual scores that a company attains and the scores are then divided by the maximum number of items that the company should be disclosing (i.e. VD $\leq 56$ items). With regard to the score value, each item disclosed will be awarded with the score of ' 1 ', while each item not disclosed will be awarded with ' 0 '. To attain the voluntary disclosure index ratio, all the scores are added and the total score is then divided by the maximum possible score (56 for this study's index). Meanwhile, similar to the past studies (e.g. Uyar \& Kiliç, 2012), corporate performance (CP) in this study is measured by calculating the return on assets (i.e. the ratio of net income to total assets (ROA)).

\section{Results and Discussions}

The Granger (1969) test is employed in this study in determining the causality directions (bidirectional, unidirectional, or neutral) between voluntary disclosure and corporate performance in the interim reports (half yearly) of the listed companies in Jordan. The test is performed in levels, that is, with no first differencing.

The outcomes of the Granger causality tests for services sector companies are shown in Table 1. As indicated by the table, the services of health care services show unidirectional causality running from VD to CP in ABMS and ICMI corporations. Also, between VD and CP in CICO Corporation, there is no directional causality. Apart from that, the educational services indicate no directional causality between VD and CP in ITSC, ZEIC and AIEI corporation. Additionally, the services of Hotels and Tourism indicate a unidirectional causality running from 


\section{VD to CP in JPTD Corporation.}

Conversely, a Bi-unidirectional causality is found running from CP to VD in MDTR Corporation, while between VD and CP in MALL, JOHT, AIHO, TAJM and ZARA Corporation, no directional causality is found. Then, for the services of transportation a unidirectional causality running from VD to CP in SHIP and SITT corporations is detected. Meanwhile, VD and CP in JETT, ALFA and TRTR corporations indicate no directional causality.

As for the Media services, the outcome indicates a unidirectional causality running from VD to CP in JOPP corporations whereas for the services of Utilities and Energy, the outcome demonstrates that a unidirectional causality is present, running from VD to CP in NAPT and JOPT Corporation. On the other hand, there is no directional causality found between VD and CP in IREL corporations, and the same outcome is also found between VD and CP in SPTI, JDFS, JITC and ABLA corporations in the services of commercial.

Table 1. Granger causality tests for services sector corporations

\begin{tabular}{|c|c|c|c|c|}
\hline Symbol & Causality Directions & F-Statistic & Prob. & Decision \\
\hline \multicolumn{5}{|c|}{ HealthCare } \\
\hline ABMS & $\mathrm{VD} \rightarrow \mathrm{CP}$ & 144.875 & 0.0528 & Uni- directional. \\
\hline \multirow[t]{2}{*}{$\mathrm{CICO}$} & $\mathrm{VD}-\mathrm{CP}$ & 0.00098 & 0.9801 & No directional causality. \\
\hline & & 2.55460 & 0.3559 & \\
\hline ICMI & $\mathrm{VD} \rightarrow \mathrm{CP}$ & 74.5931 & 0.0734 & Uni- directional. \\
\hline \multicolumn{5}{|c|}{ Educational } \\
\hline \multirow[t]{2}{*}{ ITSC } & $\mathrm{VD}-\mathrm{CP}$ & 20.9836 & 0.1368 & No directional causality. \\
\hline & & 1.83811 & 0.4046 & \\
\hline \multirow[t]{2}{*}{ ZEIC } & $\mathrm{VD}-\mathrm{CP}$ & 0.12177 & 0.7863 & No directional causality. \\
\hline & & 2.18806 & 0.3784 & \\
\hline \multirow[t]{2}{*}{ AIEI } & $\mathrm{VD}-\mathrm{CP}$ & 0.19692 & 0.7341 & No directional causality. \\
\hline & & 4.83889 & 0.2716 & \\
\hline \multicolumn{5}{|c|}{ Hotels and Tourism } \\
\hline \multirow[t]{2}{*}{ MALL } & $\mathrm{VD}-\mathrm{CP}$ & 4.37689 & 0.2839 & No directional causality. \\
\hline & & 0.38557 & 0.6462 & \\
\hline JPTD & $\mathrm{VD} \rightarrow \mathrm{CP}$ & 41.7235 & 0.0978 & Uni- directional. \\
\hline \multirow[t]{2}{*}{ JOHT } & $\mathrm{VD}-\mathrm{CP}$ & 0.88644 & 0.5192 & No directional causality. \\
\hline & & 25.3617 & 0.1248 & \\
\hline \multirow[t]{2}{*}{ AIHO } & $\mathrm{VD}-\mathrm{CP}$ & 0.06523 & 0.8408 & No directional causality. \\
\hline & & 0.24349 & 0.7082 & \\
\hline \multirow[t]{2}{*}{ TAJM } & $\mathrm{VD}-\mathrm{CP}$ & 0.00356 & 0.9621 & No directional causality. \\
\hline & & 0.73880 & 0.5480 & \\
\hline \multirow[t]{2}{*}{ MDTR } & $\mathrm{VD} \leftrightarrow \mathrm{CP}$ & 45.3523 & 0.0938 & Bi-directional. \\
\hline & & 1758.62 & 0.0152 & \\
\hline \multirow[t]{2}{*}{ ZARA } & $\mathrm{VD}-\mathrm{CP}$ & 5.58841 & 0.2548 & No directional causality. \\
\hline & & 5.34715 & 0.2598 & \\
\hline \multicolumn{5}{|c|}{ Transportation } \\
\hline \multirow[t]{2}{*}{ JETT } & $\mathrm{VD}-\mathrm{CP}$ & 10.7454 & 0.1885 & No directional causality. \\
\hline & & 0.05930 & 0.8479 & \\
\hline \multirow[t]{2}{*}{ ALFA } & $\mathrm{VD}-\mathrm{CP}$ & 0.41131 & 0.6370 & No directional causality. \\
\hline & & 0.03039 & 0.8901 & \\
\hline SHIP & $\mathrm{VD} \rightarrow \mathrm{CP}$ & 124.179 & 0.0570 & Uni- directional. \\
\hline SITT & $\mathrm{VD} \rightarrow \mathrm{CP}$ & 39.8434 & 0.1000 & Uni- directional. \\
\hline \multirow[t]{2}{*}{ TRTR } & $\mathrm{VD}-\mathrm{CP}$ & 1.53519 & 0.4323 & No directional causality. \\
\hline & & 2.60473 & 0.3531 & \\
\hline \multicolumn{5}{|c|}{ Media } \\
\hline JOPP & $\mathrm{VD} \rightarrow \mathrm{CP}$ & 675.314 & 0.0245 & Uni- directional \\
\hline \multicolumn{5}{|c|}{ Utilities and Energy } \\
\hline NAPT & $\mathrm{VD} \rightarrow \mathrm{CP}$ & 42.5756 & 0.0968 & Uni- directional. \\
\hline \multirow[t]{2}{*}{ IREL } & $\mathrm{VD}-\mathrm{CP}$ & 8.79381 & 0.2071 & No directional causality. \\
\hline & & 0.12655 & 0.7824 & \\
\hline
\end{tabular}




\begin{tabular}{lllll}
\hline JOPT & VD $\rightarrow$ CP & 118.509 & 0.0583 & Uni- directional. \\
\hline \multirow{2}{*}{ SPTI } & VD $-C P$ & Commercial & & \\
& & 0.01429 & 0.9243 & No directional causality. \\
JDFS & VD $-C P$ & 0.00257 & 0.9677 & \\
& & 3.67115 & 0.3062 & No directional causality. \\
JITC & VD $-C P$ & 14.3038 & 0.1646 & \\
& & 5.31985 & 0.2604 & No directional causality. \\
ABLA & VD $-C P$ & 0.00177 & 0.9732 & No directional causality. \\
\end{tabular}

Note. (1) $\rightarrow$ represents the unidirectional causality. (2) - shows no directional causality. (3) $\leftrightarrow$ represents the bidirectional causality.

Source: output of Eviews 7.1 econometric software.

The outcomes of the Granger causality tests for the companies in industries sector are highlighted in Table 2. From the table, it can be seen that for the Pharmaceutical and Medical Industries, no directional causality between VD and CP in MPHA, DADI and APHC Corporation can be detected, and the similar outcome is also found between VD and $\mathrm{CP}$ in INOH, ICAG, JOIC, INMJ, NATC and JOIR Corporation. Meanwhile, a unidirectional causality is found in Paper and Cardboard Industries, running from VD to CP in PERL Corporation, while no directional causality is detected between VD and CP in APCT and APCT Corporation.

Further, a unidirectional causality is detected, running from VD to CP in UADI corporations in Packaging industries, while no directional causality is found between VD and CP in EKPC corporations. As for the Food and Beverages industries, the outcome indicates that a unidirectional causality exists, running from VD to CP in JVOL corporations. However, no directional causality is detected between VD and CP in NATP, NDRA, AMAN and JODA corporations. Then, with regard to the Tobacco and Cigarettes industry, a unidirectional causality is detected running from VD to CP in ELCO Corporation. On the other hand, no directional causality is found between VD and CP in UTOB corporations.

With respect to the Mining and Extraction Industries the outcome indicates the presence of a unidirectional causality running from VD to CP in JOST, NATA, INTI, APOT, and JOWL corporations. However, no directional causality is detected between VD and CP in SLCA, AALU, NAST, JOPH and JOCM corporations. As for the Engineering and Constructing, the result indicates a unidirectional causality running from VD to CP in AJFM Corporation. On the other hand, no directional causality is detected between VD and CP in RMCC, IENG, JOPI and WOOD corporations. Then, for the Electrical Industries, a unidirectional causality is found running from VD to CP in WIRE Corporation. However, no directional causality is found between VD and CP in JNCC, MECE and AEIN corporations.

In terms of the Textiles, Leathers and Clothing industries, the outcome indicates a unidirectional causality running from VD to CP in ELZA Corporation. However, no directional causality is found between VD and CP in CELG, JOWM and WOOL corporations. Finally, the Glass and Ceramic industries show no directional causality between VD and CP in ICER corporations. However, a unidirectional causality is detected from VD to CP in JOCF Corporation.

Table 2. Granger causality tests for industries sector corporations

\begin{tabular}{|c|c|c|c|c|}
\hline Symbol & Causality Directions & F-Statistic & Prob. & Decision \\
\hline \multicolumn{5}{|c|}{ Pharmaceutical and Medical Industries } \\
\hline MPHA & $\mathrm{VD}-\mathrm{CP}$ & 2.87975 & 0.3390 & No directional causality. \\
\hline \multirow[t]{2}{*}{ DADI } & $\mathrm{VD}-\mathrm{CP}$ & 0.31225 & 0.6756 & No directional causality. \\
\hline & & 1.79010 & 0.4086 & \\
\hline APHC & $\mathrm{VD}-\mathrm{CP}$ & 0.93727 & 0.5103 & No directional causality. \\
\hline \multicolumn{5}{|c|}{ Chemical Industries } \\
\hline \multirow[t]{2}{*}{ INOH } & $\mathrm{VD}-\mathrm{CP}$ & 0.13589 & 0.7752 & No directional causality. \\
\hline & & 9.58576 & 0.1989 & \\
\hline \multirow[t]{2}{*}{ ICAG } & $\mathrm{VD}-\mathrm{CP}$ & 0.15655 & 0.7601 & No directional causality. \\
\hline & & 2.49359 & 0.3594 & \\
\hline
\end{tabular}




\begin{tabular}{|c|c|c|c|c|}
\hline \multirow[t]{2}{*}{ JOIC } & $\mathrm{VD}-\mathrm{CP}$ & 0.40061 & 0.6408 & No directional causality. \\
\hline & & 8.36359 & 0.2119 & \\
\hline \multirow[t]{2}{*}{ INMJ } & $\mathrm{VD}-\mathrm{CP}$ & 33.2435 & 0.1093 & No directional causality. \\
\hline & & 1.87218 & 0.4018 & \\
\hline \multirow[t]{2}{*}{ NATC } & $\mathrm{VD}-\mathrm{CP}$ & 0.36226 & 0.6551 & No directional causality. \\
\hline & & 0.55633 & 0.5920 & \\
\hline \multirow[t]{2}{*}{ JOIR } & $\mathrm{VD}-\mathrm{CP}$ & 0.60693 & 0.5787 & No directional causality. \\
\hline & & 0.36994 & 0.6521 & \\
\hline \multicolumn{5}{|c|}{ Paper and Cardboard Industries } \\
\hline PERL & $\mathrm{VD} \rightarrow \mathrm{CP}$ & 2225.64 & 0.0135 & Uni-directional. \\
\hline \multirow[t]{2}{*}{ APCT } & $\mathrm{VD}-\mathrm{CP}$ & 0.74256 & 0.5472 & No directional causality. \\
\hline & & 0.42313 & 0.6329 & \\
\hline \multirow[t]{2}{*}{ JOPC } & $\mathrm{VD}-\mathrm{CP}$ & 3.30760 & 0.3200 & No directional causality. \\
\hline & & 0.27150 & 0.6942 & \\
\hline \multicolumn{5}{|c|}{ Printing and Packaging } \\
\hline \multirow[t]{2}{*}{ EKPC } & $\mathrm{VD}-\mathrm{CP}$ & 0.29265 & 0.6843 & No directional causality. \\
\hline & & 0.00036 & 0.9880 & \\
\hline \multirow[t]{2}{*}{ UADI } & $\mathrm{VD} \rightarrow \mathrm{CP}$ & 554.962 & 0.0270 & Uni-directional \\
\hline & \multicolumn{4}{|c|}{ Food and Beverages } \\
\hline \multirow[t]{2}{*}{ NATP } & $\mathrm{VD}-\mathrm{CP}$ & 0.00295 & 0.9654 & No directional causality. \\
\hline & & 32.7471 & 0.1101 & \\
\hline \multirow[t]{2}{*}{ NDRA } & $\mathrm{VD}-\mathrm{CP}$ & 0.90199 & 0.5164 & No directional causality. \\
\hline & & 6.99964 & 0.2301 & \\
\hline \multirow[t]{2}{*}{ AMAN } & $\mathrm{VD}-\mathrm{CP}$ & 1.13215 & 0.4803 & No directional causality. \\
\hline & & 13.3098 & 0.1703 & \\
\hline JVOL & $\mathrm{VD} \rightarrow \mathrm{CP}$ & 116.155 & 0.0589 & Uni-directional \\
\hline \multirow[t]{2}{*}{ JODA } & $\mathrm{VD}-\mathrm{CP}$ & 8.00230 & 0.2163 & No directional causality. \\
\hline & & 11.3298 & 0.1838 & \\
\hline \multicolumn{5}{|c|}{ Tobacco and Cigarettes } \\
\hline UTOB & $\mathrm{VD}-\mathrm{CP}$ & 0.28240 & 0.6890 & No directional causality. \\
\hline & & 1.60705 & 0.4252 & \\
\hline ELCO & $\mathrm{VD} \rightarrow \mathrm{CP}$ & 79.1542 & 0.0713 & Uni-directional \\
\hline & & ing and Ex & Industrie & \\
\hline JOST & $\mathrm{VD} \rightarrow \mathrm{CP}$ & 99.9138 & 0.0635 & Uni-directional \\
\hline NATA & $\mathrm{VD} \rightarrow \mathrm{CP}$ & 204.997 & 0.0444 & Uni-directional \\
\hline INTI & $\mathrm{VD} \rightarrow \mathrm{CP}$ & 78.0013 & 0.0718 & Uni-directional \\
\hline SLCA & $\mathrm{VD}-\mathrm{CP}$ & 0.84420 & 0.5269 & No directional causality. \\
\hline & & 6.20538 & 0.2430 & \\
\hline AALU & $\mathrm{VD}-\mathrm{CP}$ & 0.30117 & 0.6805 & No directional causality. \\
\hline & & 1.13243 & 0.4802 & \\
\hline NAST & $\mathrm{VD}-\mathrm{CP}$ & 4.89596 & 0.2702 & No directional causality. \\
\hline & & 1.59553 & 0.4263 & \\
\hline JOPH & $\mathrm{VD}-\mathrm{CP}$ & 4.59103 & 0.2780 & No directional causality. \\
\hline & & 1.75893 & 0.4113 & \\
\hline JOCM & $\mathrm{VD}-\mathrm{CP}$ & 0.04542 & 0.8663 & No directional causality. \\
\hline & & 0.00465 & 0.9566 & \\
\hline APOT & $\mathrm{VD} \rightarrow \mathrm{CP}$ & 563.139 & 0.0268 & Uni-directional \\
\hline JOWL & $\mathrm{VD} \rightarrow \mathrm{CP}$ & 94.1339 & 0.0654 & Uni-directional \\
\hline & & gineering & astruction & \\
\hline RMCC & $\mathrm{VD}-\mathrm{CP}$ & 2.97011 & 0.3347 & No directional causality. \\
\hline & & 6.78584 & 0.2333 & \\
\hline IENG & $\mathrm{VD}-\mathrm{CP}$ & 0.74939 & 0.5458 & No directional causality. \\
\hline & & 0.64199 & 0.5700 & \\
\hline JOPI & $\mathrm{VD}-\mathrm{CP}$ & 0.84317 & 0.5271 & No directional causality. \\
\hline & & 0.49222 & 0.6105 & \\
\hline AJFM & $\mathrm{VD} \rightarrow \mathrm{CP}$ & 63.9264 & 0.0792 & Uni-directional \\
\hline WOOD & $\mathrm{VD}-\mathrm{CP}$ & 7.16460 & 0.2276 & No directional causality. \\
\hline & & 0.72064 & 0.5519 & \\
\hline & & Electric & tries & \\
\hline $\mathrm{JNCC}$ & $\mathrm{VD}-\mathrm{CP}$ & 0.10263 & 0.8026 & No directional causality. \\
\hline & & 38.9569 & 0.1011 & \\
\hline
\end{tabular}




\begin{tabular}{|c|c|c|c|c|}
\hline \multirow[t]{2}{*}{ AEIN } & $\mathrm{VD}-\mathrm{CP}$ & 1.41285 & 0.4453 & No directional causality. \\
\hline & & 2.83000 & 0.3414 & \\
\hline \multirow[t]{2}{*}{ MECE } & $\mathrm{VD}-\mathrm{CP}$ & 0.39304 & 0.6435 & No directional causality. \\
\hline & & 0.78827 & 0.5378 & \\
\hline WIRE & $\mathrm{VD} \rightarrow \mathrm{CP}$ & 43.4586 & 0.0958 & Uni-directional \\
\hline \multicolumn{5}{|c|}{ Textiles, Leathers and Clothing's } \\
\hline ELZA & $\mathrm{VD} \rightarrow \mathrm{CP}$ & 6389.79 & 0.0080 & Uni-directional. \\
\hline \multirow[t]{2}{*}{ CELG } & $\mathrm{VD}-\mathrm{CP}$ & 0.83084 & 0.5295 & No directional causality. \\
\hline & & 0.42789 & 0.6312 & \\
\hline \multirow[t]{2}{*}{ JOWM } & $\mathrm{VD}-\mathrm{CP}$ & 1.72826 & 0.4140 & No directional causality. \\
\hline & & 0.28333 & 0.6886 & \\
\hline \multirow[t]{2}{*}{ WOOL } & $\mathrm{VD}-\mathrm{CP}$ & 23.0131 & 0.1308 & No directional causality. \\
\hline & & 9.99247 & 0.1951 & \\
\hline \multicolumn{5}{|c|}{ Glass and Ceramic Industries } \\
\hline \multirow[t]{2}{*}{ ICER } & $\mathrm{VD}-\mathrm{CP}$ & 0.85058 & 0.5257 & No directional causality. \\
\hline & & 0.22057 & 0.7205 & \\
\hline JOCF & $\mathrm{VD} \rightarrow \mathrm{CP}$ & 1162.51 & 0.0187 & Uni-directional \\
\hline
\end{tabular}

Note. (1) $\rightarrow$ represents the unidirectional causality. (2) - shows no directional causality. (3) $\leftrightarrow$ represents the bidirectional causality.

Source: output of Eviews 7.1 econometric software.

Shown by Table 3, are the outcomes of Granger causality for services and industries companies. As indicated by the table, a unidirectional causality exists, running from VD to CP in the ASE listed companies in Jordan. Thus, it can be said that an increase in the voluntary disclosure in the half-yearly reports published by the ASE listed companies in Jordan may cause the corporate performance for these companies to also increase (Mitton, 2002; Chang, Cho, \& Shin, 2007).

Table 3. Granger causality tests for services and industries corporations

\begin{tabular}{llll}
\hline Causality Directions & F-Statistic & Prob. & Decision \\
\hline $\mathrm{VD} \rightarrow \mathrm{CP}$ & 3.13423 & 0.0775 & Uni-directional \\
\hline
\end{tabular}

Note. $\rightarrow$ represents the unidirectional causality.

Source: output of Eviews 7.1 econometric software.

The outcomes of the Granger causality tests for the companies in the services and industries sector are presented in Table 4. As shown by the table, 21 companies show unidirectional causality, while 50 companies indicate no directional causality whereas bidirectional causality is demonstrated by one company.

Table 4. Summary of granger causality tests for services and industries sector corporations

\begin{tabular}{lccc}
\hline Causality Directions & Services Sector Corporations & for industries sector corporations & All corporations \\
\hline Uni-directional & 8 & 13 & 21 \\
Bi-directional & 1 & 0 & 1 \\
No directional & 17 & 33 & 50 \\
Total of corporation & 26 & 46 & 72 \\
\hline
\end{tabular}

Also presented in Table 4 are the relationships that exist between the variables where voluntary disclosure leads to corporate performance $(\mathrm{VD} \rightarrow \mathrm{CP})$. In other words, increase in the voluntary disclosure may cause corporate performance to increase in the half-yearly reports of the ASE listed companies in Jordan. Further, the quality of voluntary disclosure is argued to have great correlation with the performance of the company (Mitton, 2002). As such, high level of transparency and quality of disclosure should lead to good governance and enhanced company performance. However, Chang, Cho, and Shin (2007) argued that voluntary disclosure intensifies the difficulty faced by the market in foretelling the performance of the company.

Aside from that, bi-directional causality is also detected between voluntary disclosure and corporate performance (VD↔CP). Simply put, increase in the voluntary disclosure may cause corporate performance to also increase 
(Mitton, 2002; Chang, Cho, \& Shin, 2007). On the other hand, increase in corporate performance may cause voluntary disclosure to increase (Camfferman \& Cooke, 2002; Chau \& Gray, 2002; Haniffa \& Cook, 2002; Kusumawati, 2006; Adelopo, 2011). Aside from that, voluntary disclosure and corporate performance appear to have no directional causality between them (VD-CP).

The non-directional causality that exists between voluntary disclosure and corporate performance (VD-CP) may be clarified by a number of reasons. First of all, Jordan had suffered from the global financial crisis and this has affected the country's economic and corporate performance. Recalling the signaling theory discussed earlier, companies with high level of corporate performance always attempt to differentiate themselves (from other companies) via internal information disclosure as a signal of their performance. Based on this notion, it can also be said that companies with low corporate performance will not disclose more information due to their low level corporate performance (Roos, Dragonetti, \& Edvinsson, 1997).

Aside from that, Jordan has to import oil and Gas from the neighbouring markets due to its limited resources. Then, as indicated by Addustour (2011), the increasing cost of energy prices for the companies has caused the cost and pricing to increase. Due to this, companies in Jordan will not disclose more information to reduce cost as voluntary disclosure is costly, such as the cost of collecting and processing information (Healy \& Palepu, 1993; Eccles \& Mavrinac, 1995). In addition to that, the ASE listed companies in Jordan are likely to avoid disclosing information that will cause harm to their competitive position (Newman \& Sansing, 1993). In fact, as reported by Addustour (2011), the major obstacle faced by the companies in Jordan is linked to unfair competition. In relation to this, the JSC had executed 365 enforcement actions in 2004 for mostly lack of proper disclosure among companies (Rosc, 2005).

\section{Conclusion and Recommendations}

The issue of information disclosure, particularly with respect to the improvement and development of voluntary disclosure for the enhancement of corporate performance, is among the major issues facing the policymakers today. Meanwhile, users value the merit of interim financial reports when they are making investment decisions. As such, feedback Granger Causality does exist between voluntary disclosure and corporate performance among the listed companies in Jordan.

The researcher hopes that this study will become the catalyst for more future interim financial reporting studies in Jordan and in other nations in which the knowledge of interim financial reporting is still underdeveloped. Aside from that, it is also hoped that this study will create opportunities and platform for a more comprehensive research in this domain.

\section{References}

Adelopo, I. (2011). Voluntary disclosure practices amongst listed companies in Nigeria. Advances in Accounting, 27(2), 338-345.

Ahmed, K., \& Courtis, J. K. (1999). Associations between corporate characteristics and disclosure levels in annual reports: A meta-analysis. The British Accounting Review, 31(1), 35-61.

Akhtaruddin, M. (2005). Corporate mandatory disclosure practices in Bangladesh. The International Journal of Accounting, 40(4), 399-422.

Akhtaruddin, M., \& Haron, H. (2010). Board ownership, audit committees' effectiveness, and corporate voluntary disclosures. Asian Review of Accounting, 18(3), 245-259. http://dx.doi.org/10.1108/13217341011089649

Albawwat, A., Ali Basah, M., \& Faizal Khairi, K. (2014). Voluntary Disclosure and Interim Financial Reporting in Jordanian Listed Companies (p. 756). The 6th Islamic Banking, Accounting and Finance Conference, Nilai, Malaysia, 23rd-24th September 2014.

Alias, N., Clark, M., \& Roudaki, J. ( 2009). The Current Disclosure Status of Interim Reporting by Malaysian Companies. Retrieved from http://ssrn.com/abstract=1464465

Allen, A., Cho, J. Y., \& Jung, K. (1999). Cross country examination of characteristics and determinants of analyst's forecast errors. The Mid-Atlantic Journal of Business, 35(2/3), 119-133. Retrieved from http://ssrn.com/abstract $=1980974$

Al-Shammari, B., \& Al-Sultan, W. (2010). Corporate governance and voluntary disclosure in Kuwait. International Journal of Disclosure and Governance, 7(3), 262-280. 
Arvidsson, S. (2003). The extent of disclosure on intangibles in annual reports (Vol. 20, p. 23). In Paper presented at the 4th annual SNEE congress in Mölle.

Barako, D. G., Hancock, P., \& Izan, H. Y. (2006). Relationship between corporate governance attributes and voluntary disclosures in annual reports: The Kenyan experience. Financial Reporting, Regulation and Governance, 5(1), 1-26.

Botosan, C. A. (1997). Disclosure level and the cost of equity capital. Accounting Review, 323-349. Retrieved from http://ssrn.com/abstract=208148

Bukh, P. N., Nielsen, C., Gormsen, P., \& Mouritsen, J. (2005). Disclosure of information on intellectual capital in Danish IPO prospectuses. Accounting, Auditing \& Accountability Journal, 18(6), 713-732. http://dx.doi.org/10.1108/09513570510627685

Camfferman, K., \& Cooke, T. E. (2002). An analysis of disclosure in the annual reports of UK and Dutch companies. Journal of International Accounting Research, 1(1), 3-30. http://dx.doi.org/10.2308/jiar.2002.1.1.3

Chang, J., Cho, Y. J., \& Shin, H. H. (2007). The change in corporate transparency of Korean firms after the Asian financial crisis: An analysis using analysts' forecast data. Corporate Governance: An International Review, 15(6), 1144-1167.

Chau, G. K., \& Gray, S. J. (2002). Ownership structure and corporate voluntary disclosure in Hong Kong and Singapore. The International Journal of Accounting, 37(2), 247-265.

Cheng, E., \& Courtenay, S. M. (2006). Board composition, regulatory regime and voluntary disclosure. The International Journal of Accounting, 41(3), 262-289.

Chow, C. W., \& Wong-Boren, A. (1987). Voluntary financial disclosure by Mexican corporations. Accounting Review, 533-541.

Cooke, T. E. (1989). Disclosure in the corporate annual reports of Swedish companies. Accounting and Business Research, 19(74), 113-124.

Eccles, R. G., \& Mavrinac, S. C. (1995). Improving the corporate disclosure process. Sloan Management Review, $36(4), 11-25$.

Elsayed, M. O., \& Hoque, Z. (2010). Perceived international environmental factors and corporate voluntary disclosure practices: An empirical study. The British Accounting Review, 42(1), 17-35.

Eng, L. L., \& Mak, Y. T. (2003). Corporate governance and voluntary disclosure. Journal of Accounting and Public Policy, 22(4), 325-345.

Foster, G. (1986). Financial statement analysis (2nd ed.). Englewood Cliffs, New Jersey: Prentice-Hall, Inc.

Ghazali, N. A., \& Weetman, P. (2006). Perpetuating traditional influences: voluntary disclosure in Malaysia following the economic crisis. Journal of International Accounting, Auditing and Taxation, 15(2), 226-248.

Gordon, L. A., Loeb, M. P., \& Sohail, T. (2010). Market Value of Voluntary Disclosures Concerning Information Security. MIS Quarterly, 34(3).

Haniffa, R. M., \& Cooke, T. E. (2002). Culture, corporate governance and disclosure in Malaysian corporations. Abacus, 38(3), 317-349.

Healy, P. M., \& Palepu, K. G. (1993). The effect of firms' financial disclosure strategies on stock prices. Accounting Horizons, 7(1), 1.

Kusumawati, D. N. (2006). Profitability and corporate governance disclosure: An Indonesian study. Simponsium Nasional Akuntansi, 9.

Lang, M., \& Lundholm, R. (1993). Cross-sectional determinants of analyst ratings of corporate disclosures. Journal of Accounting Research, 246-271.

Lev, B., \& Penman, S. H. (1990). Voluntary forecast disclosure, nondisclosure, and stock prices. Journal of Accounting Research, 49-76.

Lopes, A. B., \& De Alencar, R. C. (2010). Disclosure and cost of equity capital in emerging markets: The Brazilian case. The International Journal of Accounting, 45(4), 443-464.

Mangena, M., \& Tauringana, V. (2007). Corporate compliance with non-mandatory statements of best practice: The case of the ASB statement on interim reports. European Accounting Review, 16(2), 399-427. 
Mathuva, D. (2012). The Determinants of Forward-looking Disclosures in Interim Reports for Non-financial Firms: Evidence from a Developing Country. International Journal of Accounting and Financial Reporting, 2(2), 2162-3082.

Meek, G. K., Roberts, C. B., \& Gray, S. J. (1995). Factors influencing voluntary annual report disclosures by US, UK and continental European multinational corporations. Journal of International Business Studies, $555-572$.

Mitton, T. (2002). A cross-firm analysis of the impact of corporate governance on the East Asian financial crisis. Journal of Financial Economics, 64(2), 215-241.

Newman, P., \& Sansing, R. (1993). Disclosure policies with multiple users. Journal of Accounting Research, 92-112.

Raffournier, B. (1995). The determinants of voluntary financial disclosure by Swiss listed companies. European Accounting Review, 4(2), 261-280.

Robbins, W. A., \& Austin, K. R. (1986). Disclosure quality in governmental financial reports: An assessment of the appropriateness of a compound measure. Journal of Accounting Research, 24(2), 412-421.

Roos, G., Dragonetti, N. C., \& Edvinsson, L. (1997). Intellectual capital. In J. Roos (Ed.). Macmillan.

ROSC. (2005). Report on the observance of standards and codes, Corporate Governance Country Assessment, electronic version. Published Feb 3, 2005, by the jointWorld Bank-IMF program of reports on the observance of standards and codes, Jordan, bjor_rocs_cg.pdfN.

Saravanakumar, S., Mahadevan, A., Sairam Subramaniam, B., \& Aarthy, A. (2012). An Empirical Investigation on the Announcement of Corporate Quarterly Results. International Journal of Multidisciplinary Research, 2 .

Uyar, A., \& Kiliç, M. (2012). Value relevance of voluntary disclosure: Evidence from Turkish firms. Journal of Intellectual Capital, 13(3), 363-376. http://dx.doi.org/10.1108/14691931211248918

\section{Appendix A. Voluntary Disclosure Index Checklist}

\begin{tabular}{l} 
NO Category \\
\hline Strategic Information \\
General corporate information \\
1. Brief history of the company. \\
2. Address, telephone, fax. \\
3. Description of organizational structure. \\
4. General description of business/activities. \\
5. The currency used for the preparation of financial statements.
\end{tabular}

\section{Corporate strategy}

6. Statement of corporate strategy and objectives- general

7. Statement of corporate strategy and objectives- financial

8. Statement of corporate strategy and objectives- marketing

9. Statement of corporate strategy and objectives- social

10. Impact of strategy on current results

11. Impact of strategy on future results

\section{Research and development}

12. corporate policy on research and development

13. Information about staff training and development

\section{Future prospects}

14. Qualitative forecasts of sales (revenues) 

15. Quantitative forecasts of sales (revenues)
16. Qualitative forecasts of profits
17. Quantitative forecasts of profits
18. Qualitative forecast of cash flow
19. Quantitative forecast of cash flow
20. Forecast earnings per share
21. Discussion of competitive position of the company

\section{NONFINANCIAL INFORMATION}

\section{Information about board of directors}

22. Age of the directors

23. Educational qualifications (academic and professional)

24. Commercial experience of the executive directors

25. Commercial experiences of the non-executive directors

26. Shareholdings in the company

27. Number of shares owned by management

28. Number of shares owned by directors

29. Directors' remuneration

\section{Social responsibility}

30. Number of employees

31. Categories of employees by gender

32. Categories of employees by function

33. Identification of senior management and their functions

34. Names and salaries of senior management

\section{Social policy}

35. Charitable donations (amount)

36. Sponsoring public health, sporting and recreational projects

37. Sponsoring educational conferences, seminars or art exhibits

38. Funding scholarship programmers' or activities

\section{FINANCIAL INFORMATION}

\section{Performance indicators:}

39. Historical figures for last years or more (or as long as companies formation)

40. Profit

41. Total assets

\section{Financial ratios}

42. Profitability ratios

43. Liquidity ratios

44. Leverage ratios

45. Growth rate on earnings

46. Return on capital employed

47. Return on shareholders' equity

48. Other ratios 
49. Market capitalizations at half year-end

50. Market capitalization trend

51. Size of Shareholdings

52. Type of shareholders (for example, institutions , and individuals)

53. Geographical distributions of shareholders

Foreign currency information:

54. Impact of foreign exchange fluctuations on Current results

55. Foreign currency exposure management description

56. Major exchange rates used in the accounts

\section{Copyrights}

Copyright for this article is retained by the author(s), with first publication rights granted to the journal.

This is an open-access article distributed under the terms and conditions of the Creative Commons Attribution license (http://creativecommons.org/licenses/by/3.0/). 